\title{
The Prisoner's Dilemma and economics 101: Do active learning exercises correlate with student performance?
}

\begin{abstract}
Chong Hyun Christie Byun ${ }^{1}$
Abstract: The importance of active learning in the classroom has been well established in the field of Economic education. This paper examines the connection between active learning and performance outcomes in an Economics 101 course. Students participated in single play simultaneous move game with a clear dominant strategy, modeled after the Prisoner's Dilemma. The hypothesis is that if a student understands the Prisoner's Dilemma and the relevant assumptions in Economic theory, he will choose the dominant strategy in the game. But will his choice be correlated with his performance on two important metrics? Empirical evidence indicates that there is a correlation between a student's performance on the Prisoner's Dilemma game and his performance on the subsequent in-class exam and in the course overall.
\end{abstract}

Keywords: active learning, game theory, Prisoner's Dilemma

\section{Introduction}

The importance of active learning in the classroom has been well established in the field of the scholarship of teaching and learning. A survey of the literature shows that the research in active learning techniques in the classroom across a variety of disciplines can lead to improved understanding and retention of course material, as well as improved outcomes on exams.

To that end, this paper examines student performance on an in-class active learning exercise and how that performance correlates with performance on a subsequent in-class exam and the overall score in the course. Students in a Principles of Economics Course (Eco101) participated in a simple Prisoner's Dilemma game, and the game results were analyzed in terms of correlation with learning outcomes on assessments. The question is whether their performance on the game is correlated to their performance on a subsequent midterm exam and their overall letter grade in Eco101. The empirical evidence indicates some relationship between a student's choosing the dominant strategy in the game and higher scores on the subsequent in-class exam and overall performance in the course.

\section{Literature Review}

There is a substantial body of literature investigating the connection between active learning practices in the classroom and performance on exams and courses in Economics. Siegfried and Fels (1979) present a survey on the literature on teaching college economics and new instructional techniques. Simpkins and Barbour (1998) investigate innovative ways of using the Internet to promote active learning in Economics courses. Cardell et al. (1996) discuss the use of a combined lecture and laboratory course format to construct an active learning

\footnotetext{
${ }^{1}$ Wabash College, Department of Economics, 301 W. Wabash Ave., Crawfordsville, IN 47933, (765) 361-6260, byunc@wabash.edu
} 
environment. Buchs and Blanchard (2011) develop an innovative role-playing exercise to demonstrate the concept of sustainable development in a graduate economics course. Brouhle (2011) explores the use of classroom clickers to promote active engagement in class, with an application toward oligopolies. Lewis (2011) uses the case of Bates College's decision to purchase a tradable discharge permits for sulfur dioxide as an active learning exercise for students to learn about cap and trade practices, with a positive relationship between the exercise and learning outcomes.

Across a variety of other disciplines, there is extensive work on active learning practices in the classroom and improved student performance outcomes. Yoder and Hochevar (2005) find improved outcomes on exams in Psychology courses as a result of using active learning practices in the classroom. Coakley and Sousa (2013) establish that active and other contemporary learning practices lead to improved student engagement and retention of knowledge in an introductory business course. Nguyen and Trimarch (2010) investigate the use of technology in and out of the classroom using MyEconLab or Aplia. Their research indicates that these types of technologies enable students to engage more fully in their coursework via online contacts with instructors and peers via digital means, and give students more opportunities to be involved in active discussion in large courses. In the STEM fields, Freeman et al. (2014) conduct a comparison of student performance outcomes in courses with traditional lecture sections and active learning sections. They find evidence of improvement in exam scores across STEM disciplines. McCarthy and Anderson (2000) conduct a similar experiment in history and political science courses, and find that students who participated in active learning practices in the classroom had improved outcomes on exams than students who were in traditional, lecture-based courses.

\section{Motivation}

One of the principle assumptions of economic theory is that individual agents are rational, utility maximizing individuals. As such, agents will make decisions that will give them the best possible outcome or highest utility. Carrying that assumption over into producer theory, economic theory posits that firms will choose a level of production that maximizes profits. In the model of a perfectly competitive market (with a large number of firms), each firm chooses its level of production based upon a standard profit maximizing rule, independent of what other firms are choosing. The firm's choice of its quantity of production has no influence over the equilibrium price of the good on the market, since it is only one firm among many.

But in the model of an oligopolistic market structure, there are only a handful of (typically) large firms in the market, and thus a firm's choice of the quantity it produces does matter. In oligopoly, the firms are large enough to have an influence on the market price. There is interdependence among these firms in that the action taken by one firm has an impact on the outcomes for the other firms in the market. As a consequence, each participant realizes this interdependence and must make a production decision that he knows will be affected by what other firms choose. All in all, an oligopolistic market structure is such that one or several of the competing firms can have an influence on market price and possibly exert market dominance through their actions.

The Prisoner's Dilemma can be used to illustrate the oligopolistic market structure in Economics. The classic Prisoner's Dilemma game is as follows. Two criminals, A and B, have been captured by the police and are being questioned in separate interrogation rooms about their 
involvement in a burglary. The police tell the two suspects that they face prison time for their alleged crime. The evidence against the suspects is circumstantial, although it is enough to put each suspect in prison for a short sentence.

There are three possible outcomes in the Prisoner's Dilemma. One outcome is if both criminals stay silent and do not confess anything to the police. This outcome is labeled (Silent, Silent). If so, they will each receive a short sentence, say 2 years, based on the circumstantial evidence.

However, the police offer the following deal to each suspect. If the suspect cooperates with the police and gives enough evidence to put the crime on his partner (who stays silent), the cooperator will go free, while his partner will be put away for the maximum prison time of 20 years. This outcome is labeled (Confess, Silent) or (Silent, Confess).

The third outcome is if both suspects cooperate with the police in the hopes of pinning the entire crime on his partner (Confess, Confess). In this case, the police have enough evidence on both criminals to put both away for 10 years each.

Overall, the Prisoner's Dilemma illustrates how interdependence between the two suspects has an impact on the outcome for both. What one suspect chooses has a bearing on what his and his partner's outcomes will be. If a suspect considers each option in turn, the option he should always choose is to Confess, regardless of what his partner will choose. If he chooses Silent, he faces the possibility of receiving the maximum prison sentence of 20 years if his partner chooses Confess. If he chooses Silent and his partner also chooses Silent, both will face a 2 year prison sentence. However, if he had chosen Confess while his partner chose Silent, then he himself would have gone free. As such, a criminal should never choose Silent, since there is always another option that will lead to a better outcome, regardless of what his partner chooses. In this case, the option of Confess is known as the dominant strategy, the strategy a player will always choose regardless of what his partner chooses. Since both criminals go through the same thought process, both will choose Confess and wind up with 10 year sentences.

The outcome (Confess, Confess) is known as the Nash Equilibrium (sometimes called the "no regrets" equilibrium). This is the outcome in which neither party has regret about what choice he made in the game after the outcome of the game is revealed. If either player had chosen otherwise, he would have had regret about the choice he had made. In this case, the Confess option is known as the dominant strategy since it outperforms all other possible options. For instance, if player A had chosen Silent while player B chose Confess, player A would receive the 20 year sentence and B would have gone free. Obviously player A would have regret about not choosing Confess as well. If both players choose Silent, this would mean 3 year sentences for both, instead of the possible freedom. Thus, each player's best response is to choose Confess, and the Nash Equilibrium is the outcome where neither player could have gotten a better outcome by changing his response.

In the Prisoner's Dilemma game, there is an element of interdependence, as each player's outcome is dependent on what his partner will select. The game illustrates the ideas of both competition (for the biggest payoff) and interdependence (your payoff will depend upon not only your choice but your partner's choice). It is a lead-in to the topics of oligopolies and monopolistic competition, and it demonstrates how "big business" can work in the real world. Some applied examples discussed in class include smartphone manufacturers, energy drink companies, and the oil industry, where each is a case of a group of (mostly) large firms competing on the market with products that are close (but not perfect) substitutes, and operate on a framework with a high degree of interdependence between firms. 
A simple example of the Prisoner's Dilemma as applied to industry is the introduction of the Apple iPhone. Speculation about Apple's new cell phone release was one of the most closely watched in the industry, and true to prediction, the iPhone changed the face of the cell phone industry, as other companies rushed to produce similar smartphones wireless capabilities and touch screen technology ${ }^{2}$. In this case, Apple was the industry leader and other companies were followers. This was evident from the intense interest surrounding Apple's new high tech cell phone release (the first iPhone) and how it sparked the rush by other cell phone producers to launch a similar device.

Based on this industry example, the actions and resulting payoffs for cell phone manufacturers can be illustrated by the Prisoner's Dilemma in the following way. Two cell phone manufacturers play a simultaneous move game in which the decision is to produce either a high-tech cell phone or a low-tech one. A cell phone manufacturer can continue to produce a low-tech cell phone, which is inexpensive to produce with existing technology and infrastructure. If the competitor company does the same, then the firms will receive equal market share of sales and each receive a medium level of profit. However, if one firm decides to produce a high-tech cell phone (in this case, Apple with its smartphone with touch screen technology), consumers will be attracted to the new technology and buy that instead of the old, low-tech cell phone. Apple will capture the market for cell phones, receive high profits, and its competitor will receive none. The high-tech cell phone is expensive to develop and manufacture. If both companies choose to produce it, they will split the market and each receives low profits.

With this knowledge, should competing cell phone companies choose to produce the lowtech option? In the Prisoner's Dilemma, the answer is No. If a company chooses the low-tech option while its competitors choose the high-tech option, the low-tech company would receive zero profits. Producing the high-tech phone, while expensive, results in either low profit or high profit, both of which are better than zero profit. Thus there is no incentive for a company to choose to produce the low-tech phone, because to produce the high-tech one always yields a bigger payoff than choosing low-tech, regardless of what the opponent chooses. The firms should choose to produce the high-tech phone, even if it means greater cost in research and development and production. Therefore, both companies will produce the high-tech phone, split the market, and each receive low profits. A player will always choose the option that gives him the highest payoff given what his partner could possibly choose. In short, he would choose the dominant strategy in the game. In this case, each cell phone company should choose to produce the high tech phone.

The example above is used in class to illustrate the simple prisoner's dilemma game and motivate deeper thought and classroom discussion about these principles. The example brings a natural connection to an in-class exercise in which students participate in a Prisoner's Dilemma game, witness the outcome, and use it to think more deeply about the strategy he should or should not follow. The active learning component of this exercise helps students understand the ideas behind the Prisoner's Dilemma, including the formal concepts of a dominant strategy and the Nash Equilibrium. The idea is that if a student acts according to the standard economic assumption that all individuals are rational, utility maximizing individuals, he would choose an option that gives him the greatest possible payoff. If a student has fully understood the game and the standard assumptions of Economics, including the classic assumption of rationality and utility maximization mentioned previously, he would choose the dominant strategy in order to get the highest potential payoff. But would successful performance on this game be correlated

\footnotetext{
${ }^{2}$ Mehta, Stephanie, 2006, "How Apple Could Rock Wireless", Fortune Magazine.
} 
with performance in the course? An examination of the outcome from a version of the Prisoner's Dilemma played in class provides empirical evidence that there is a positive correlation between a student's use of the dominant strategy and his performance on a subsequent in-class exam and overall letter grade in the course.

Of course, a correlation between performance on the Prisoner's Dilemma and performance in Eco101 may be tenuous, as various factors go into performance in both of these arenas. Other factors, such as mathematical or analytical ability and training, along with having had an Economics course at a previous institution also play significant roles. In addition, the ability to act as a cold, rational actor in the Prisoner's Dilemma might not necessarily translate into good performance in the overall course. However, it is useful to examine the empirical evidence and see if any correlation can be found between performance on this game and learning outcomes in Eco101. An investigation of the data from three semesters of Eco101 indicates that there is a positive relationship between a student's performance (choosing the dominant strategy) on the Prisoner's Dilemma game and his performance in the course.

\section{The Game}

The Grade Game was conducted over three semesters of Eco101 at a private liberal arts college for men in Indiana. The Eco101 course is a semester long course with no pre-requisites, covering a variety of Microeconomics topics during the first seven weeks of the semester, and Macroeconomics topics in the last seven weeks. The Game Theory module is typically covered in week 6 of the semester, immediately after the Perfect Competition and Monopoly modules. Prior to the Game Theory module, students have a thorough grounding in basic Producer Theory in the Perfect Competition and Monopoly modules. The Game Theory module includes the topics of the Prisoner's Dilemma, dominant strategies, and the Nash Equilibrium (among other topics). All these Game Theory topics are applied toward an understanding of the oligopolistic market structure in economics.

The Grade Game is structured as a single play simultaneous move game with a dominant strategy, and is modeled after the classic Prisoner's Dilemma (see Kuhn, 2014; Dixit \& Skeath, 1999). The Game is played in class after the students receive a brief introduction and overview of the rules. Conducting the Game in class is necessary in order to give each student equal time to participate and also allows the instructor to manage the workings of the play. In-class play of the Game also allows the instructor to enforce the restriction of communication between students in the classroom. The classroom is a face-to-face room so that the instructor can ensure compliance of all the rules of the game. Students are paired randomly in groups of two by the instructor in order to minimize possible bias stemming from a student selecting a partner with whom he is well acquainted or who may perform similarly to him. Each student is issued a game card with the fully illustrated game table on it. In order to make the game realistic and applicable to students in their situation, the outcomes of the game are designated as points that can be won or lost on the next in-class exam (in which one of the topics to be covered is Game Theory). A general explanation of the applicability of the Prisoner's Dilemma to oligopoly and monopolistic competition is also provided so that students understand the connection between game theory and economic theory. A discussion of dominant strategies and the Nash Equilibrium is held after the Game is played and the results of each team's play is announced. On the game table, students have the option of choosing either MORE points or LESS points on the next exam. If both students choose the LESS option, they will each receive 1 extra point on the next exam. If both 
choose the MORE option, they will receive zero extra points. If one student chooses MORE while his partner chooses LESS, he will receive 2 extra points and the partner will receive -10 points. The game table is shown in Figure 1.

\section{THE GRADE GAME}

YOUR NAME

YOUR PARTNER

\begin{tabular}{|l|l|l|}
\hline & Your partner chooses More & Your partner chooses Less \\
\hline You choose More & $\mathbf{( 0 ,}, 0)$ & $(\underline{\mathbf{2}},-10)$ \\
\hline You choose Less & $\mathbf{( - 1 0}, 2)$ & $(\underline{\mathbf{1}}, 1)$ \\
\hline
\end{tabular}

You get to choose if you want MORE points on Exam \#2 or LESS points.

You get to choose only yours, but the actual result depends on what your partner chooses combined with your choice. Your free point outcome is the one in bold underline text in the parentheses - the first one in the ordered pair. Your partner's grade is the second one.

CIRCLE YOUR CHOICE OF FREE POINT(S) FOR YOURSELF NOW

MORE LESS

Figure 1. The Grade Game.

Students were led through an explanation of the rules of the game and the game table payoffs, with clear instructions not to communicate with their partners prior to making their decisions. The credibility of the game is ensured by repeated announcements by the instructor that these points will be awarded (or deducted) on the next exam, with a reminder to read the table carefully and consider what option is the best choice, given what your partner might possibly choose. The game is played once, with each student first reading the instructions and the table in the handout, and then circling either MORE or LESS to indicate his choice of possible bonus or penalty points on the next exam. ${ }^{3}$

\section{Outcome of the game: Data Analysis}

The Grade Game was conducted in Eco101 sections, with one section per semester in each of the Spring 2013, Fall 2013, and Spring 2014 semesters. A total of 75 students enrolled in these sections, 71 played the Grade Game, and four were absent on the days the Game was conducted. The participation rate was $94.67 \%$ over the three sections.

Students who chose the LESS option were categorized as the Cooperators, and those who chose the MORE option were the Non-cooperators. A total of 49 students (or 69\%) of the

\footnotetext{
${ }^{3}$ Penalty or bonus points were not actually awarded on the subsequent in-class exam. This announcement was made at the end of the class period at the conclusion of the Grade Game.
} 
Byun, C.H.C.

students chose to cooperate, and a total of 22 students (or $31 \%$ ) chose not to cooperate. Summary statistics for each category are shown in Table 1.

Table 1

Descriptive Statistics

\begin{tabular}{|c|c|c|c|c|}
\hline & & $\begin{array}{l}\text { ALL } \\
\text { STUDENTS }\end{array}$ & COOPERATORS & NON-COOPERATORS \\
\hline & & $N=71$ & $n=49$ & $n=22$ \\
\hline \multicolumn{5}{|c|}{ EXAM 2} \\
\hline - & Mean & 70.6 & 68.6 & 74.9 \\
\hline - & SD & 15.5 & 16.2 & 12.7 \\
\hline - & Median & 73 & 73 & 73.5 \\
\hline
\end{tabular}

\section{OVERALL}

SCORE

\begin{tabular}{|c|c|c|c|c|}
\hline - & Mean & 72.7 & 69.8 & 79.2 \\
\hline - & SD & 14.9 & 16.2 & 8.4 \\
\hline - & Median & 74.4 & 73.4 & 78.1 \\
\hline
\end{tabular}

Correlation Coefficient corr(grade game, exam score) $=-0.19$

Correlation coefficient corr(grade game, overall score $)=-0.29$

A preliminary examination of the summary statistics for the in-class exam (the exam on which the Game Theory topic was included) shows that the average score for the Cooperators was $68.6 \%$, with a standard deviation of 16.4 , and the median score was $73 \%$. The average score on the exam for the Non-cooperators was $74.9 \%$ with an SD of 13 , and a median score of $73.5 \%$. Here, the evidence indicates that the Non-cooperators performed better, on average, than the Cooperators.

Each student's overall score in the course was calculated based on performance on the two in-class exams (each worth $25 \%$ of the overall score), the final exam (worth $30 \%$ ), homework assignments (15\%) and attendance/participation (5\%). For the overall score in the course, the Cooperators' average was $69.8 \%$ with an SD of 16.3 , and the median was 73.4 . For the Non-cooperators, the average overall score in the course was $79.2 \%$ with an SD of 8.6 , and a median of 78.1. Again, a preliminary examination of the evidence shows that Non-cooperators received higher scores in the course compared to the Cooperators, indicating a possible causal link between performance on the Grade Game and performance in the course.

Examining the groups of Cooperators and Non-cooperators in turn, a review of the lower scoring students shows the following. For the Cooperators, 21 out of 49 students $(42.9 \%)$ scored below $70 \%$ (designated a $\mathrm{C}$-) on the in-class exam, and 9 out of $22(40.9 \%)$ of the Noncooperators scored below $70 \%$. For the overall score in the course, 19 out of $49(38.8 \%)$ received an overall score below $70 \%$, whereas only 2 out of 22 of the Non-cooperators $(9.1 \%)$ received a score lower than $70 \%$ in the course.

Based on this examination of summary statistics for the in-class exam and the overall score in the course, the data indicate that the Non-cooperators perform better on all counts. The correlation coefficient was calculated for the performance on the Grade Game the two respective 
assessments by assigning the Cooperators a 1 , and Non-cooperators a 0 and. The correlation coefficient for the Grade Game and the in-class exam scores was -0.18 , and it was -0.29 for the Grade Game and the overall scores in the course. The correlation coefficients indicate a negative linear relationship between performance on the Game and performance on the two assessment metrics.

The data for the Grade Game and scores on the in-class exam are also shown in a scatterplots with a fitted regression line in Figures 2. The slope of the regression line indicates a negative relationship between Cooperation in the Grade Game and performance on the in-class exam, predicting that a student will score 6.7 points lower on the in-class exam if he chooses to Cooperate in the Game.

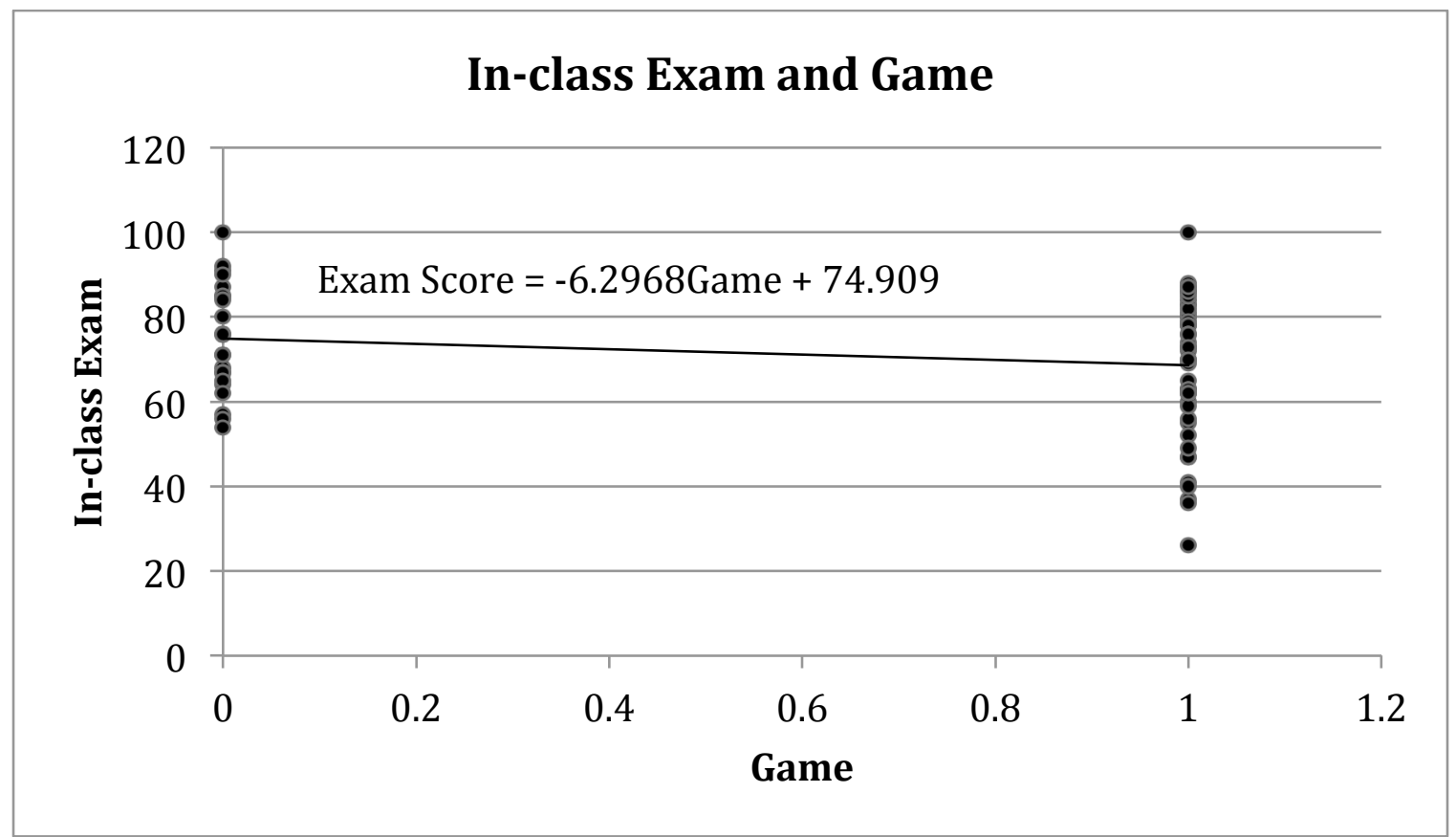

Figure 2. In-class Exam and Game.

A scatterplot and fitted regression line for the data on the Grade Game and the overall score in the course is displayed in Figure 3. It also indicates a negative relationship between Cooperation and overall performance in the course. Based on the fitted line, we predict that a student will score 9.3 points lower overall if he chooses to Cooperate in the Grade Game (significant at the 5\% level). Table 2 shows the regression outputs from the estimations of the two models. 


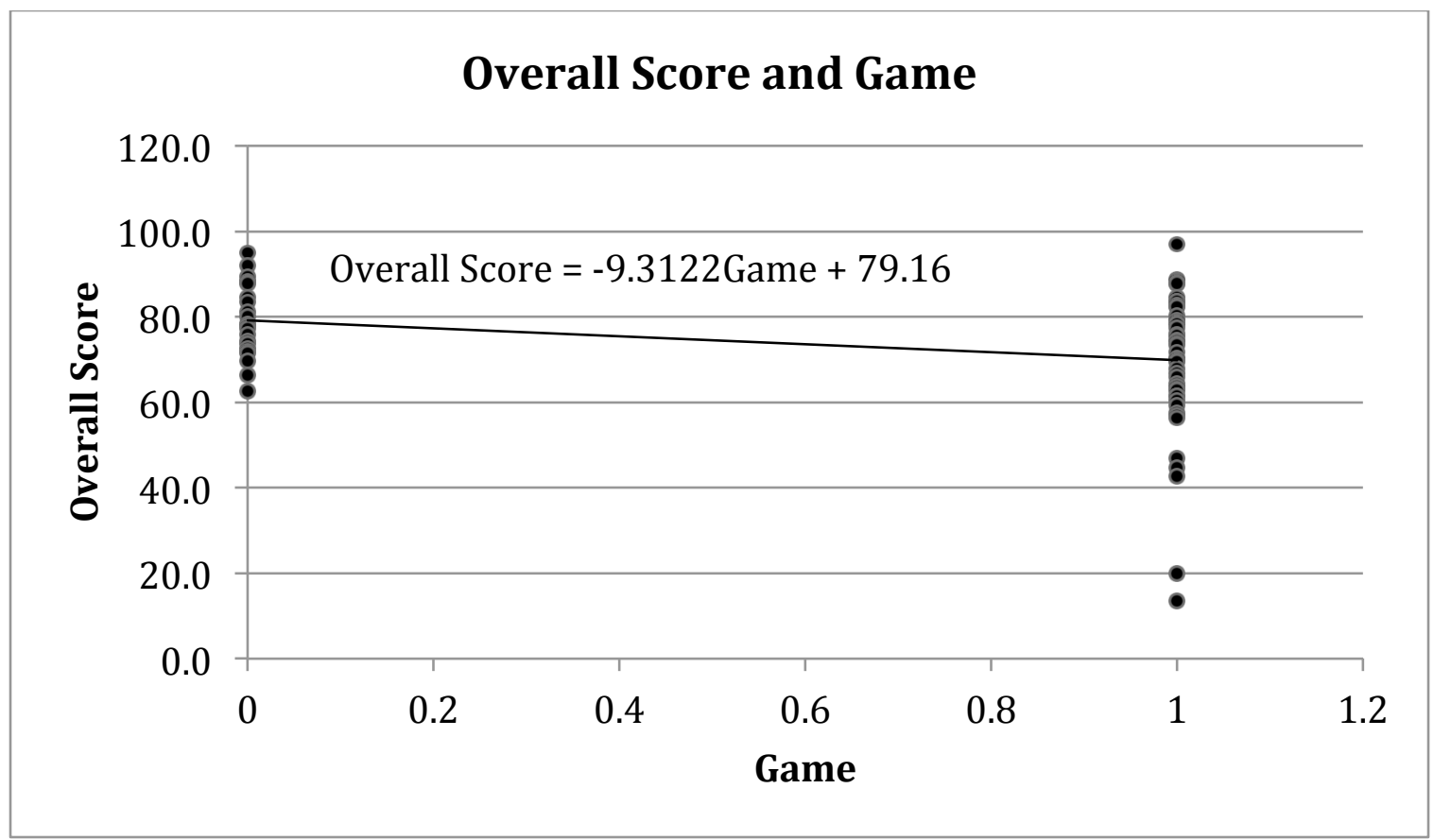

Figure 3. Overall Score and Game.

Table 2

Regression Output

\begin{tabular}{lll}
\hline $\begin{array}{l}\text { DEPENDENT } \\
\text { VARIABLE }\end{array}$ & MODEL 1 & MODEL 2 \\
\hline In-class exam score & -6.29 & -- \\
& $(3.96)$ & -- \\
\hline Intercept & 74.91 & \\
\hline & $(3.29)$ & \\
\hline Overall Score & & $-9.31^{*}$ \\
& -- & $(3.70)$ \\
\hline Intercept & & 79.16 \\
& -- & $(3.07)$ \\
\hline$N=71$ & &
\end{tabular}

Estimated SEs in parenthesis

${ }^{*} p<.05$ 
The question of whether there is a difference in the mean scores between the Cooperators and Non-cooperators was investigated for both sets of scores. A t-test for the difference in means was conducted for both the in-class exam scores and for the overall scores in the course. For the in-class exam scores, the calculated t-statistic was -1.73, with 27 degrees of freedom. The associated p-value was $9.4 \%$, indicating that the test statistic was significant at the $10 \%$ level, but not the 5\% level. For the overall scores in the course, the calculated t-statistic was -3.17 , with 32 degrees of freedom. The associated p-value was $0.34 \%$, indicating that the test statistic was significant at both the $5 \%$ and $1 \%$ levels. The difference in means tests shows that there is a highly statistically significant difference for the overall scores in the class for the Cooperators versus the Non-cooperators, but not for the in-class exam scores.

\section{Conclusion}

The importance of active learning practices in the classroom has been well established across a variety of disciplines. These practices correlate with higher levels of student engagement with the material and improved performance outcomes on exams and course grades. This paper seeks to establish a connection between performance on a version of the Prisoner's Dilemma game played in class with subsequent performance on an in-class exam and with on overall performance in the course. The data indicated a positive relationship between performance on the Grade Game and performance on two metrics in Eco101. Students who chose the dominant strategy (the Non-cooperators) tended to do better, on average, than students who did not choose that strategy (the Cooperators). This was true for both the subsequent in-class exam and for the overall score in Economics 101. The estimation of a bivariate regression model for the relationship between choice of strategies and overall score in the class indicated that the Cooperators were predicted to score 9.3 points lower overall in the course, with this finding significant at the 5\% level. A difference of means test also indicated that the difference of the average overall score in the course between the Cooperators and Non-cooperators was statistically significant. In general, it appears that a student's performance on the Grade Game is correlated with his overall score in Eco101.

The implications of this empirical study for the scholarship of teaching and learning are many. If student performance on the Grade Game is correlated with performance on two important metrics (scores on a subsequent in-class exam and the overall score in the class), it seems that a thorough understanding of the Grade Game and the Prisoner's Dilemma would improve student performance in these areas. This implies that students should have a firm grounding and understanding of the elements of the Game, including the topics of dominant strategy and the Nash Equilibrium. This is an important conclusion for the instructor who may be using this active learning exercise in the classroom. An instructor who uses the Grade Game in class may wish to follow up with a reinforcement of the above topics (interdependence, dominant strategy, Nash Equilibrium) and how they relate to the topic of oligopoly in order to ensure that students are understanding and retaining this material.

One thing that is striking about the data on the Grade Game is the relatively high level of cooperation among the players. Other studies across a variety of disciplines have sought possible explanations for cooperation in the Prisoner's Dilemma in single and repeated play games (see Fehr \& Fischbacher, 2003; Doebeli \& Hauert, 2005; Cooper et al., 1996). Khadjavi and Lange (2013) conduct an experiment in which the Prisoner's Dilemma is played by actual prisoners. They found a relatively high degree of cooperation among the participants. Their explanation is

Journal of the Scholarship of Teaching and Learning, Vol. 14, No. 5, December 2014. 
that the "social structure inside the prison is such that you survive better if you cooperate" 4 . While the social structure of a small, all-male liberal arts college in the Midwest may arguably have some parallels to the prison system, further research must be done to investigate the connection between college social norms and outcomes on the Prisoner's Dilemma. This may be a topic of future research.

\section{Acknowledgements}

Special thanks to the Wabash College Department of Economics and to Ethan Hollander, Associate Professor of Political Science at Wabash College.

\section{References}

Becker, W. E. (1997). Teaching economics to undergraduates. Journal of Economic Literature, 35 (3), 1347-1373.

Brouhle, K. (2011). Exploring strategic behavior in an oligopoly market using classroom clickers. The Journal of Economic Education, 42 (4), 395 - 404. doi: 10.1080/00220485.2011.606093

Buchs, A., \& Blanchard, O. (2011). Exploring the concept of sustainable development through role-playing. The Journal of Economic Education, 42 (2), 388 - 394. doi:

10.1080/00220485.2011.606089

Cardell, N.S., Fort. R., Joerding, W., Inaba, F., Lamoreaux, D., Rosenman, R., Stromsdorfer, E., \& Bartlett, R. (1996). Laboratory-based experimental and demonstration initiatives in teaching undergraduate economics. The American Economic Review, Papers and Proceedings of the $108^{\text {th }}$ Annual Meeting of the American Economic Association, 86 (2), 454 - 459.

Coakley, L. A., \& Sousa, K. J. (2013). The effect of contemporary learning approaches on student perceptions in an introductory business course. Journal of the Scholarship of Teaching and Learning, 13 (3), 1-22.

Cooper, R., DeJong, D. V., Forsythe, R., \& Ross, T. W. (1996). Cooperation without reputation: Experimental evidence from Prisoner's Dilemma games. Games and Economic Behavior, 12, 187-218. doi: 10.1006/game.1996.0013

Dixit, A., \& Skeath, S. (1999). Games of Strategy. New York, London: W.W. Norton \& Company.

Doebeli, M., \& Hauert, C. (2005). Models of cooperation based on the Prisoner's Dilemma and the Snowdrift game. Ecology Letters, 8, 748-766. doi: 10.1111/j.1461-0248.2005.00773.x

\footnotetext{
${ }^{4}$ Mohan, Geoffrey, 2013, “Economists Finally Test Prisoner's Dilemma on Prisoners”, Los Angeles Times, July 24, 2013. 
Byun, C.H.C.

Fehr, E., \& Fischbacher, U. (2003). The nature of human altruism. Nature, 23, 785-791. doi: 10.1038 /nature 02043

Freeman, S., Eddy, S. L., McDonough, M., Smith, M. K., Okoroafor, N., Jordt, H., \& Wenderoth, M. (2014). Active learning increases student performance in science, engineering, and mathematics. Proceedings of the National Academy of Sciences, 111(23), 8410-8415. doi: 10.1073/pnas.1319030111

Khadjavi, M., \& Lange, A. (2013). Prisoners and their dilemma. Journal of Economic Behavior and Organization, 92, 163-175. doi: 10.1016/j.jebo.2013.05.015

Kuhn, S. (2014). Prisoner's Dilemma. In E. N. Zalta (Ed.), The Stanford Encyclopedia of Philosophy. Retrieved from: http://plato.stanford.edu/entries/prisoner-dilemma/

Lewis, L. Y. (2011). A virtual field trip to the real world of cap and trade: Environmental economics and the EPA $\mathrm{SO}_{2}$ allowance auction. The Journal of Economic Education, 42 (4), 354 - 365. doi: 10.1080/00220485.2011.606086

McCarthy, J. P., \& Anderson, L. (2000). Active learning techniques versus traditional teaching styles: Two experiments from history and political science. Innovative Higher Education, 24 (4), 279 - 294. doi: 10.1023/B:IHIE.0000047415.48495.05

Mehta, S. (2006). How Apple could rock wireless. Fortune Magazine.

Mohan, G. (2013). Economists finally test Prisoner's Dilemma on prisoners. Los Angeles Times.

Nguyen, T. T., \& Trimarchi, A. (2010). Active learning in introductory economics: Do MyEconLab and Aplia make any difference? International Journal for the Scholarship of Teaching and Learning, 4 (1).

Reay, D., David, M., \& Ball, S. (2001). Making a difference? Institutional habituses and higher education choice. Sociological Research Online, 5 (4). doi: 10.5153/sro.548

Siegfried, J. T., \& Fels, R. (1979). Research on teaching economics: A survey. Journal of Economic Literature, 17 (3), 923-969.

Simpkins, S., \& Barbour, J. (1998). Surfing for success in economics: A student's guide to the internet. Prentice-Hall.

Thomas, L. (2002). Student retention in higher education: The role of institutional habitus. Journal of Education Policy, 17 (4), 423-442. doi: 10.1080/02680930210140257

Valcarcel, V. J. (2013). Instituting a monetary economy in a semester-long macroeconomics course. The Journal of Economic Education, 44 (2), 129 - 141. doi:

$10.1080 / 00220485.2013 .770337$ 
Watts, M., \& Becker, W. E. (2008). A little more than chalk and talk: Results from a third national survey of teaching methods in undergraduate economics courses. Journal of Economic Education, 39 (3), 237 - 286. doi: 10.3200/JECE.39.3.273-286

Yoder, J. D., \& Hochevar, C. M. (2005). Encouraging active learning can improve students' performance on examinations. Teaching of Psychology, 32 (2), 91 - 95. doi:

$10.1207 / \mathrm{s} 15328023$ top3202_2 